\title{
STOSUNKI KRÓLESTWA MAROKA Z PAŃSTWAMI EUROPEJSKIMI W OKRESIE PANOWANIA HASANA II (1961-1999): WYBRANE ASPEKTY
}

\author{
Agnieszka Syliwoniuk-Wapowska \\ Uniwersytet Warszawski \\ Wydział Nauk Politycznych i Studiów Międzynarodowych \\ ORCID ID: https://orcid.org/ 0000-0002-0055-2943 \\ Email: a.syliwoniuk-wapowska@uw.edu.pl
}

\begin{abstract}
Streszczenie: W artykule ukazane zostały główne aspekty relacji Królestwa Maroka z wybranymi państwami Europy - Francją, Hiszpanią, Maltą oraz Stolicą Apostolską - w okresie panowania króla Hasana II (1961-1999). W pracy podniesiony został także wątek stosunków królestwa ze Wspólnotą Europejską. W celu rekonstrukcji relacji Maroka z krajami europejskimi sięgnięto po źródła pierwotne, wykorzystano zasoby internetowe oraz przeprowadzono krytyczną analizą literatury przedmiotu.
\end{abstract}

Słowa kluczowe: Maroko, Hasan II, Europa, polityka zagraniczna, stosunki międzynarodowe

\section{WSTĘP}

Ze względu na położenie geograficzne, bliskość kulturową oraz wspólnotę losów historycznych Królestwo Maroka zalicza się do grona państw Maghrebu, czyli arabskiego Zachodu (w języku arabskim al-Maḡrib oznacza „Zachód”). Ponadto, Maroko stanowi najdalej wysuniętą na zachód część świata arabskiego, co znajduje swoje odzwierciedlenie także w nazwie państwa: Al-Mamlaka al-Mağribiyya ${ }^{1}$. Jest też państwem afrykańskim oraz krajem, który przez swoją kolonialną przeszłość związany jest z Europą.

W świetle historii i położenia geograficznego, a także sytuacji politycznej i gospodarczej w czasie panowania króla Hasana II (1961-1999) relacje z państwami Europy stanowiły istotną linię marokańskiej polityki zagranicznej. Przybierały one formę zarówno współpracy bilateralnej, jak i multilateralnej. Przez

\footnotetext{
1 W dosłownym tłumaczeniu z języka arabskiego: „Królestwo Zachodnie”.
} 
większość okresu sprawowania władzy przez Hasana II polityka zagraniczna Maroka rozgrywała się w cieniu zimnej wojny. W rzeczywistości zimnowojennej, której granice wyznaczał podział świata na dwa bloki, Maroko prowadziło politykę neutralności i niezaangażowania. Jako przykład działań wpisujących się w nurt tejże polityki można podać ewakuację wojsk oraz baz Francji i Hiszpanii w 1961 roku. Ponadto, należąc do grona państw-założycieli, Maroko brało też czynny udział w pracach Ruchu Państw Niezaangażowanych [Żebrowski 2001: 135]. Warto dodać, że zasada niezaangażowania została podkreślona m.in. w styczniu 1961 roku podczas spotkania głów państw afrykańskich w Casablance (tzw. Grupa Casablanca) [Charte de Casablanca 1964: 754]. Należy jednak zauważyć, że zasady neutralności i niezaangażowania stosowane były w marokańskiej polityce zagranicznej w sposób dość selektywny - niejednokrotnie Królestwu Maroka bliżej było do zachodniej strefy wpływów niż do wschodniej². Jednocześnie trzeba podkreślić, że Maroko nie opowiadało się przeciwko Związkowi Radzieckiemu $\mathrm{i}$, jeśli pozostawało to $\mathrm{w}$ zgodzie $\mathrm{z}$ interesami królestwa, podejmowało $\mathrm{z}$ nim współpracę. Za jedną z przyczyn większego dystansu w stosunku do ZSRR niż do Zachodu można uznać kwestie ideologiczne - radziecka ideologia komunistyczna postrzegana była jako potencjalne zagrożenie dla istnienia ustroju monarchicznego w Maroku3 . Problem ten nie dotyczył relacji z państwami Europy Zachodniej.

Celem artykułu jest przedstawienie głównych aspektów relacji Maroka z wybranymi państwami Europy w okresie panowania króla Hasana II (1961-1999) oraz ukazanie różnorodności cechującej współpracę Maroka z jego europejskimi partnerami. Obok stosunków z dwoma głównymi europejskimi partnerami Królestwa Maroka - Francją i Hiszpanią - zarysowane zostały także relacje z Maltą i Stolicą Apostolską. Skupienie uwagi na relacjach z tymi państwami nie ma charakteru przypadkowego. Władze marokańskie przywiązywały i wciąż przywiązują wiele uwagi do relacji z Francją i Hiszpanią, dążąc do budowy jak najlepszych stosunków z tymi państwami. Jeżeli chodzi o Maltę, to w opisywanym okresie prowadziła onapodobnie jak Maroko - politykę neutralności i niezaangażowania oraz pozostawała otwarta na kontakty ze światem arabskim. Z kolei relacje ze Stolicą Apostolską są świadectwem otwartości religijnej, która postrzegana jest jako jedna z kluczowych wartości charakteryzujących kulturę polityczną w Maroku oraz wykorzystywana do kreowania korzystnego wizerunku królestwa na arenie międzynarodowej. Ponadto, z uwagi na postępujący $\mathrm{w}$ omawianym czasie proces integracji europejskiej oraz kontekst zimnowojenny ważny wątek podniesiony w pracy stanowią stosunki królestwa ze Wspólnotą Europejską/Unią Europejską.

2 Jako naturalną konsekwencję tego stanu rzeczy uznać należy fakt, że po zakończeniu zimnej wojny król Hasan II dążył do nawiązania dobrych stosunków z NATO. W 1995 roku Maroko uzyskało członkostwo w Zgromadzeniu Północnoatlantyckim oraz możliwość posiadania swojego przedstawiciela w sztabie NATO [Żebrowski 2001: 140].

3 Stąd mogła wynikać stosunkowo niewielka popularność komunistów w Maroku.

4 Wartość ta jest silnie ugruntowana w kulturze politycznej Maroka i odnosi się nie tylko do relacji islamu z chrześcijaństwem, ale przede wszystkim do relacji islamu z judaizmem. 
W pracy zastosowano metodę historyczną, która pozwala na badanie genezy zjawisk politycznych oraz ujmowanie ich aspektów strukturalnych, funkcjonalnych oraz genetycznych w sposób łączny [Chodubski 2008: 127]. W artykule uwzględniony został kontekst historyczny stosunków Maroka z wybranymi państwami Europy. Jest to zasadne z uwagi na postrzeganie historyzmu jako naczelnej dyrektywy metodologicznej politologii [Ryszka 1984: 301]. Poza przeprowadzoną na potrzeby pracy krytyczną analizą literatury przedmiotu - w przeważającej mierze obcojęzycznej - w celu rekonstrukcji relacji Maroka z krajami europejskimi sięgnięto po źródła pierwotne oraz wykorzystano zasoby internetowe. Analiza dokumentów przeprowadzona została w oparciu o porozumienia ze Wspólnotą Europejską oraz Maltą, jak również odnoszące się do relacji marokańsko-maltańskich wystąpienia premiera Malty w parlamencie ${ }^{5}$.

\section{RELACJE Z FRANCJĄ}

Najważniejszym europejskim partnerem Maroka w stosunkach międzynarodowych była Francja, co wynikało przede wszystkim z historycznych relacji łączących oba kraje - od podpisania traktatu feskiego w 1912 roku do odzyskania niepodległości w 1956 roku większość ziem marokańskich znajdowała się pod protektoratem francuskim. Czynnikami przyczyniającymi się do rozwoju stosunków pomiędzy tymi państwami były też bliskość geograficzna, silne zależności ekonomiczne, liczna społeczność imigrantów marokańskich we Francji oraz postrzeganie kultury i języka francuskiego przez znaczną część Marokańczyków jako atrakcyjnych, co ma swoje źródła w dawnych relacjach kolonialnych.

Relacje marokańsko-francuskie miały charakter wszechstronny i obejmowały zarówno kooperację polityczną, jak również kulturową i gospodarczą. $\mathrm{Na}$ polu współpracy gospodarczej francuska obecność w królestwie była szczególnie dobrze zauważalna. Jak podaje Janusz Żebrowski około 30\% marokańskiego importu pochodziło z Francji, a jej udział w eksporcie dóbr z Maroka kształtował się na podobnym poziomie. Kraj ten był też największym inwestorem zagranicznym w Królestwie Maroka (około 25\% lokowanych rocznie inwestycji) i jego głównym wierzycielem [Żebrowski 2001: 136]. Michael Willis i Nizar Messari wskazują, że w 1999 roku Francja była odbiorcą 36\% marokańskiego eksportu. Z tego kraju pochodziło też $26 \%$ marokańskiego importu oraz ponad połowa transferów pieniężnych przesyłanych do ojczyzny przez marokańskich pracowników na emigracji [Willis, Messari 2003: 162].

Rysami na relacjach marokańsko-francuskich były dwie sprawy: poparcie udzielone przez Maroko sprawie niepodległości Algierii oraz morderstwo Mah-

5 Przywołane w niniejszej pracy teksty porozumień zawartych pomiędzy Maltą a Marokiem oraz wystąpień premiera Doma Mintoffa w parlamencie zostały udostępnione autorce do celów naukowych przez Departament Informacji, wchodzący w skład struktury Kancelarii Premiera Malty. 
diego Ben Baraki. Odnosząc się do pierwszej ze wspomnianych kwestii, należy wskazać, że Maroko - jako państwo, które odzyskało niepodległość po długim okresie zależności kolonialnej - popierało analogiczne dążenia innych państw arabskich, w tym Algierii. W poparciu udzielanym Algierczykom władze marokańskie dostrzegały szansę na uzyskanie bardziej korzystnego rozwiązania problemu delimitacji granicy algiersko-marokańskiej. Jak twierdzi Jacques Benoist-Méchin, król Muhammad V odmawiał prowadzenia rozmów na ten temat z władzami francuskimi, ponieważ uważał, że ta sprawa powinna zostać rozstrzygnięta bezpośrednio pomiędzy dwoma niepodległymi państwami [Benoist-Méchin 2010: 206-207]. Plany marokańskiego monarchy pokrzyżowała algierska wojna o niepodległość, której końca nie dane mu było doczekać ${ }^{6}$. Dodatkowo, Marokańczycy wyrażali brak zaufania do działań Francji w tej sferze. Mariusz Malinowski podaje, że twierdzili oni, iż Francuzi przesuwali granicę marokańsko -algierską na korzyść Algierii - swojego ówczesnego departamentu [Malinowski 2004: 73-76, 79-80].

Jeżeli chodzi o morderstwo Mahdiego Ben Baraki, to doprowadziło ono do poważnego kryzysu we kontaktach marokańsko-francuskich. Mahdi Ben Baraka był znanym politykiem opozycji, przewodził Narodowemu Związkowi Sił Ludowych - partii o orientacji radykalnie lewicowej. Po odkryciu spisku na życie Hasana II w 1963 roku wielu czołowych działaczy tego ugrupowania zostało aresztowanych, a Ben Baraka wyjechał do Francji [Madeyska 2008: 167-168]. Widząc stale pogłębiającą się przepaść pomiędzy nim samym a opozycją, Hasan II postanowił złagodzić podziały. Mając to na uwadze, w 1965 roku monarcha podjął kroki w kierunku umożliwienia powrotu Mahdiego Ben Baraki do kraju. Niestety, stało się to za późno - jesienią 1965 roku polityk został porwany i zamordowany ${ }^{7}$ W 1966 roku oba państwa odwołały swoich ambasadorów. Relacje pozostawały zamrożone do grudnia 1970 roku [Malinowski 2004: 30, 40], po czym powróciły do dawnej formy przyjaznych kontaktów.

W okresie sprawowania funkcji głowy państwa przez Françoisa Mitteranda (1981-1995) Francja dążyła do utrzymania możliwie dobrych relacji z Algierią, Marokiem i Tunezją. Jak wskazuje Katarzyna Stachurska, pewną komplikację w tym zakresie tworzyło stanowisko francuskiej Partii Socjalistycznej - przy-

6 Porozumienie o delimitacji granicy pomiędzy Algierią a Marokiem zostało podpisane w 1972 roku w Algierze.

7 C.R. Pennell wspomina, że w 2001 roku ogłoszono, że w wyniku śledztwa prowadzonego na zlecenie władz Francji odnaleziono - we Francji i w Maroku - dowody świadczące o tym, że Mahdi Ben Baraka zmarł wskutek tortur w jednym z mieszkań w Paryżu. Następnie jego ciało zostało przewiezione do Maroka, gdzie zaginęło. Zbrodnia została dokonano z udziałem byłych agentów francuskich służb specjalnych, ale oskarżenie o zlecenie morderstwa skierowano przeciwko generałowi Muhammadowi Ufkirowi. Przypuszcza się, że dążący do zwiększenia swoich wpływów politycznych Ufkir postrzegał Ben Barakę jako groźną przeszkodę na swojej drodze. Co do ewentualnych związków Hasana II z tą sprawą, C.R. Pennell wskazuje, że: „[n]ie udało się ustalić z pewnością czy król był uwikłany w te czyny” [Pennell 2009: 253]. 
chylne Algierii, niesprzyjające Maroku oraz Tunezji - które było szczególnie zauważalne w kwestii oceny przestrzegania praw człowieka w tych państwach. W tym świetle ważnym czynnikiem było też poparcie udzielone przez Algierię dla Polisario w konflikcie o Saharę Zachodnią. Dodatkowo, żona prezydenta, Danielle Mitterand, otwarcie opowiadała się po stronie Polisario. W rezultacie relacje francusko-marokańskie w tym okresie były raczej chłodne, pomimo, iż prezydent podejmował działania ukierunkowane na łagodzenie napięć. Poprawa stosunków politycznych pomiędzy Francją a Marokiem nadeszła, gdy prezydenturę objął Jacques Chirac (1995-2007). W drugiej połowie lat 90. XX wieku relacje bilateralne pomiędzy dwoma krajami przebiegały pomyślnie. Dialog polityczny znajdował swoje odbicie również na płaszczyźnie społeczno-gospodarczej. Francuskie przedsiębiorstwa prowadziły rozległe inwestycje Maroku, zaś władze republiki - dążąc do utrzymania silnych relacji gospodarczych - zaznaczały swoją obecność poprzez program polityczny i intensywne inicjatywy kulturalne. Co więcej, sytuacja ta wpływała korzystnie także na relacje Maroka z Unią Europejską [Stachurska 2004: 44-46, 49-51].

\section{RELACJE Z HISZPANIĄ}

Drugim państwem Europy, z którym Maroko utrzymywało ważne relacje była Hiszpania - najbliższy europejski sąsiad królestwa. Jak zauważa Víctor Morales Lezcano, stosunki te sięgają swoimi korzeniami wieków XV i XVI, kiedy to Hiszpanie zdobywali kolejne posiadłości w Afryce Północnej [Morales Lezcano 2006: 400]. Ponadto, należy pamiętać, że w opisywanym okresie Hiszpania przeszła głębokie przemiany ustrojowe, których cezurą była śmierć generała Francisco Franco w 1975 roku. Od końca lat 80. XX wieku Hiszpania dążyła do wzmocnienia relacji z Marokiem, szczególnie w wymiarze gospodarczym. W rezultacie, do końca lat 90. XX wieku stała się drugim po Francji najważniejszym partnerem handlowym Maroka [Willis, Messari, 2003: 162]. Można zatem stwierdzić, że w czasie panowania króla Hasana II kształt stosunków marokańsko-hiszpańskich nie był jednoznaczny. Problemy, które przez wiele lat w sposób istotny wpływały na relacje dwóch państw wynikały w dużej mierze $\mathrm{z}$ hiszpańskiego kolonializmu w Afryce Północnej. Pierwszym z nich była sprawa dekolonizacji Sahary Hiszpańskiej, drugim - roszczenia do hiszpańskich enklaw w Maroku.

Ziemie marokańskie stanowiły przedmiot zainteresowania Hiszpanów od przełomu XV i XVI wieku. Początkiem kolonialnej obecności Hiszpanów w tej części Afryki Północnej było zajęcie Melilli w 1497 roku [Dziubiński 1983: 208 209], końcem zaś - wycofanie się z ziem saharyjskich. 14 listopada 1975 roku w Madrycie przedstawiciele rządów Hiszpanii, Maroka i Mauretanii podpisali traktat, na mocy którego trzy państwa miały wspólnie zarządzać Saharą do lutego 1976 roku. 12 stycznia 1976 roku Maroko i Mauretania rozlokowały swoje armie w strefach przekazanych im przez Hiszpanię [Pennell 2009: 258]. Sahara Hiszpań- 
ska przestała być kolonią państwa europejskiego, jednak status tych ziem do dziś nie został uregulowany. Od odzyskania niepodległości w 1956 roku - powołując się na historyczne i tradycyjne związki tych ziem z Marokiem - władze marokańskie dokładają wszelkich starań w celu ich przyłączenia do terytorium królestwa. Dążenia te wpisują się w nurt marokańskiego rewindykacjonizmu, stanowiącego istotną linę polityki zagranicznej królestwa. Pozostając na tym gruncie należy dodać, że 4 stycznia 1969 roku Hiszpania zwróciła Królestwu Maroka enklawę Ifni [Pérez García 2003: 219]. Nie zmienił się jednak status pozostałych posiadłości graniczących z Marokiem, w tym przed wszystkim enklaw Ceuta i Melilla.

Spory pomiędzy Marokiem a Hiszpanią toczyły się także na płaszczyznach rolnictwa i rybołówstwa, a zatem w tych sferach, w których oba państwa widziały swój konkretny i wymierny interes ekonomiczny. Rybołówstwo historycznie stanowiło ważną gałąź stosunków hiszpańsko-marokańskich, zaś prawa rybaków hiszpańskich do połów ryb na Atlantyku mają wielowiekową tradycję. Jak zauważają María del Mar Holgado Molina i María del Sol Ostos Rey, porozumienia dotyczące rybołówstwa miały żywotne znaczenie dla Hiszpanii i były narzędziem wykorzystywanym przez władze marokańskie w celu uzyskania rozmaitych korzyści, w tym politycznych, finansowych czy handlowych [Holgado Molina, Ostos Rey 2002: 189]. W tym świetle warto dodać, że Hiszpania zajmowała istotne miejsce wśród inwestorów zagranicznych i partnerów gospodarczych Królestwa Maroka.

Pomimo pewnych zawirowań, relacje Maroka z Francją i Hiszpanią w okresie panowania Hasana II co do zasady układały się pomyślnie. Wyjście z zależności kolonialnej od dwóch państw europejskich oznaczało dla Maroka konieczność redefinicji stosunków z nimi oraz ich rozwoju na zasadach partnerskich, co było konsekwentnie realizowane w omawianym czasie. Należy także zaznaczyć, że do dziś oba państwa europejskie zajmują istotne miejsce w polityce zagranicznej królestwa.

\section{RELACJE ZE STOLICĄ APOSTOLSKĄ}

Interesującym wątkiem w kontekście relacji Maroka doby Hasana II ze światem zachodnim są relacje ze Stolicą Apostolską, które zostały nawiązane 15 stycznia 1976 roku [Diplomatic Relations...]. W tym świetle warto wspomnieć, że 30 sierpnia 1985 roku na zaproszenie Hasana II Maroko odwiedził papież Jan Paweł II. Można uznać, że wydarzenie to miało wymiar historyczny: była to pierwsza - i jak dotąd jedna $z$ dwóch [Apostolic journey...] - oficjalna podróż głowy Kościoła Katolickiego do Maroku. Jednym z jej najważniejszych punktów było spotkanie papieża z Marokańczykami na stadionie w Casablance, ukazujące otwarty charakter tej wizyty. Podróż ta oraz jej przebieg miały podkreślić wagę, jaką do dialogu międzyreligijnego przywiązywali papież Jan Paweł II oraz król Hasan II. W świetle prowadzonej przez marokańskiego monarchę polityki zagra- 
nicznej, stanowiła ona przykład otwartości na świat zachodni oraz będące jedną z podstaw jego tożsamości wartości chrześcijańskie. Tym samym przyczyniła się do budowania pozytywnego wizerunku Maroka na arenie międzynarodowej, ukazując jego ,umiarkowanie" w sferze religijnej oraz brak poparcia dla radykalnego islamu. Ponadto, w wymiarze polityki wewnętrznej, wizyta papieża może także być postrzegana jako gest wykonany w kierunku (niewielkiej) społeczności chrześcijańskiej zamieszkującej Maroko, głównie Casablankę.

Z uwagi na niezbyt silny wpływ religii i kultury chrześcijańskiej na życie społeczne oraz politykę królestwa, można uznać, że relacje Maroka ze Stolicą Apostolską w opisywanym czasie miały wymiar przede wszystkim symboliczny. Ze strony marokańskiej ich nawiązanie było możliwe dzięki wartościom leżącym u podstaw kultury politycznej w Maroku (przede wszystkim otwartość i umiarkowanie religijne), a także sprzyjającym dialogowi postawom króla i przedstawicieli elit królestwa. Ponadto, mając na uwadze złożoną sytuację społeczną i polityczną w państwach arabskich w okresie panowania Hasana II (m.in. wynikającą z dawnych zależności kolonialnych niechęć do Zachodu wyrażaną otwarcie przez niektóre środowiska) oraz silną dominację islamu w tej części świata już sam fakt nawiązania formalnych stosunków ze Stolicą Apostolską stanowi element nieszablonowy, a tym samym godny podkreślenia. Za praktyczną stronę tychże relacji uznać należy to, iż wniosły one wkład one do kształtowania korzystnego wizerunku Maroka na forum międzynarodowym oraz w oczach opinii publicznej, zarówno krajowej, jak i zagranicznej.

\section{RELACJE Z MALTA}

Godnym uwagi przykładem współpracy bilateralnej są stosunki marokańsko -maltańskie. Do ich rozwoju przyczyniły się w dużej mierze otwarta na Europę polityka zagraniczna Hasana II, proarabska polityka zagraniczna ówczesnego premiera Malty Doma Mintoffa oraz polityka niezaangażowania prowadzona oficjalnie przez oba państwa. W odpowiedzi na zaproszenie premiera Maroka, Ahmada Osmana w dniach 27-28 listopada 1974 roku wizytę w Maroku złożył premier Malty, Dom Mintoff. Maltański szef rządu został przyjęty przez króla Hasana II oraz premiera Osmana w Fezie. Owocem spotkania było nawiązanie stosunków dyplomatycznych pomiędzy Marokiem a Maltą na poziomie ambasadorów [Stqarrija mill-Prim Ministru... 1974].

Współpraca Maroka i Malty znalazła swoje odzwierciedlenie w czterech porozumieniach podpisanych 22 stycznia 1976 roku podczas wizyty marokańskiego szefa rządu, Ahmada Osmana w Valletcie. Pierwszy z dokumentów odnosił się do sfery kultury i nauki. Wspólne działania miały być podejmowane również w dziedzinie edukacji, sportu, sztuki i technologii [Cultural and Scientific Cooperation Agreement... 1976]. Drugie z porozumień regulowało kwestie z zakresu współpracy ekonomicznej i technicznej, przede wszystkim: rybołówstwo, konstrukcję 
statków, rolnictwo, turystykę, przemysł, energetykę, transport i komunikację oraz każdą inną dziedzinę, w której współpraca obu państw mogłaby przynieść wymierne efekty [Economic and Technical Cooperation Agreement... 1976]. Trzeci akt odnosił się do stosunków handlowych pomiędzy Marokiem a Maltą. Porozumienie zawierało także dwie listy, na których wymienione były dobra, jakie mogły być eksportowane przez Maroko na Maltę i oraz przez Maltę do Maroka ${ }^{8}$. Czwarte z porozumień wówczas zawartych dotyczyło zniesienia wiz. W kontekście realiów zimnowojennych, wydaje się ono być szczególnie interesujące. Zgodnie z postanowieniami aktu obywatele Malty podróżujący do Maroka praz obywatele Maroka udający się w podróż na Maltę - jeśli pozostawali tam nie dłużej niż trzy miesiące - nie podlegali obowiązkowi posiadania wizy [Agreement (...) concerning the Abolition of Visas 1976]. Warto zaznaczyć, że wspomniane porozumienia otwierały drogę do dalszych, bardziej szczegółowych ustaleń odnoszących się do zagadnień związanych z nauką, rybołówstwem, rzemiosłem i przemysłem. Tytułem przykładu warto wskazać, że jedną z konkretnych decyzji podjętych wówczas dotyczyła budowy na Malcie jednego lub dwóch statków na zamówienie marokańskiego rządu [Stqarrija mill-Prim Ministru... 1976].

\section{RELACJE Z EUROPEJSKĄ WSPÓLNOTĄ GOSPODARCZĄ I WSPÓLNOTĄ EUROPEJSKĄ}

Obok bilateralnych stosunków z państwami Europy Maroko utrzymywało także relacje z Europejską Wspólnotą Gospodarczą. Waga tych relacji związana jest $\mathrm{z}$ faktem, iż wraz z pogłębiającą się integracją pewne aspekty stosunków państw europejskich z państwami trzecimi nie mogły pozostać uregulowane (wyłącznie) w ramach współpracy dwustronnej. Odnosiło się to szczególnie do kwestii, które miały wymiar gospodarczy.

Ponadto warto też zwrócić uwagę na pomysł stowarzyszenia ze Wspólnotą, który pojawił się w kręgach dyplomacji marokańskiej w 1963 roku. W 1969 roku została podpisana pierwsza umowa pomiędzy EWG a Marokiem, która przyznawała królestwu przywileje celne w zakresie eksportu towarów marokańskich na rynki państw członkowskich EWG [Żebrowski 2001: 126-132]. W 1972 roku EWG ogłosiła Globalną Politykę Śródziemnomorską (Global Mediterranean

8 Integralne części aktu stanowiły dwie listy wymieniające enumeratywnie produkty, które mogły być eksportowane przez oba państwa. Lista A odnosiła się do dóbr eksportowanych przez Maroko na Maltę i zawierała 69 pozycji; na liście B znajdowało się 47 rodzajów artykułów eksportowanych przez Maltę do Maroka. Listy zostały sporządzone w sposób bardzo szczegółowy. Do wyrobów eksportowanych przez Maroko zaliczono między innymi gumę do żucia, koronki oraz arkusze gumy na podeszwy butów. Wśród towarów eksportowanych przez Maltę wymieniono między innymi peruki, oprawki do okularów, plastikowe skrzynki na butelki. Należy dodać, że w porozumieniu zaznaczono, iż przedmiotami wymiany handlowej mogą być także inne dobra, niewymienione z nazwy w tymże dokumencie [Trade Agreement... 1976]. 
Policy) [Tsoukalis 1977], którą postrzegać można jako próbę zdefiniowania relacji z państwami Śródziemnomorza. Inicjatywa ta skupiała się na rozwoju wymiany handlowej, która miała być podstawą relacji pomiędzy EWG i państwami partnerskimi. W konsekwencji, 27 kwietnia 1976 roku w Rabacie strony zawarly kolejną umowę, która rozszerzała współpracę o zagadnienia z zakresu handlu, współpracy gospodarczej, finansów i szereg spraw socjalnych oraz związanych z zatrudnieniem [Cooperation Agreement... 1978]. Wprowadzenie w życie postanowień aktu doprowadziło do wzrostu poziomu wymiany handlowej między Marokiem a krajami Europejskiej Wspólnoty Gospodarczej.

W świetle relacji marokańsko-wspólnotowych należy wspomnieć, że w lipcu 1987 roku królestwo oficjalnie ubiegało się o nadanie statusu członkostwa, co wzbudziło konsternację wśród państw członkowskich. Z uwagi na pozaeuropejskie położenie geograficzne Maroka oraz zasadnicze odmienności w treści tożsamości Marokańczyków (m.in. elementy arabskie i muzułmańskie) wniosek spotkał się z odmową [Jarecka-Stępień 2018: 425].

W okresie pozimnowojennym nastąpiła intensyfikacja relacji gospodarczych i politycznych pomiędzy Wspólnotą Europejską a Królestwem Maroka. Ramy współpracy wyznaczały zasady zawarte w deklaracji podpisanej podczas konferencji, która odbyła się w Barcelonie 27 i 28 listopada 1995 roku. Deklaracja barcelońska określiła podstawy partnerstwa eurośródziemnomorskiego, w zakresie którego zawierano dwustronne układy stowarzyszeniowe. 26 lutego 1996 roku doszło do podpisania układu o stowarzyszeniu Maroka ze Wspólnotą Europejską (wszedł w życie 1 marca 2000 roku). W dokumencie uregulowane zostały relacje marokańsko-wspólnotowe przede wszystkim w tak istotnych dziedzinach, jak: współpraca polityczna, handlowa, przemysłowa, naukowa, techniczna, finansowa i przepływ kapitału. Postanowienia aktu w znacznej mierze skupiały się wokół wymiany handlowej, w tym wokół handlu produktami rybołówstwa i rolnymi. Strony wyraziły też chęć prowadzenia dialogu politycznego, który stwarzał perspektywy wzmocnienia relacji i wzajemnego zrozumienia pomiędzy stronami oraz wprowadzenia większej stabilizacji w regionie śródziemnomorskim [EuroMediterranean Agreement... 2000: 0002-0204].

Mając na uwadze postanowienia opisanych powyżej umów Michael Willis i Nizar Messari wyrażają pogląd, że Maroko nie było usatysfakcjonowane warunkami, które uzyskało. Dotyczyło to przede wszystkim eksportu produktów rolnych, które należały do głównych towarów sprzedawanych do Europy. Możliwości Maroka w tym zakresie zostały ograniczone ze względu na presję śródziemnomorskich państw członkowskich Wspólnoty Europejskiej. Państwa te żywiły obawy, iż sprzedaż marokańskich produktów rolnych po niższych cenach uderzy w możliwości sprzedażowe ich własnych rolników na rynku wspólnotowym. Zgodnie z argumentacją przedstawioną przez przywołanych autorów, Maroko zgodziło się na mało korzystne warunki w dużej mierze dlatego, że nie miało innego wyboru. Po pierwsze, z żadnym innym regionem świata królestwo nie prowadziło równie intensywnej wymiany handlowej, co z Europą. Po drugie 
zaś, władzom marokańskim zależało na utrzymaniu dobrych relacji z państwami europejskimi, ponieważ mogły się one okazać korzystne na innych polach - na przykład w kontekście różnych form wsparcia finansowego, udzielanego królestwu przez kraje europejskie [Willis, Messari 2003: 161].

\section{ZAKOŃCZENIE}

W okresie postkolonialnym stosunki z państwami europejskimi - postrzegane zarówno przez pryzmat relacji dwustronnych, jak też relacji ze Europejską Wspólnotą Gospodarczą oraz Wspólnotą Europejską - były dla Królestwa Maroka niezwykle ważne. Kluczowymi partnerami Maroka na arenie międzynarodowej pozostawały Francja i Hiszpania, jednak w zakresie kreowania polityki zagranicznej, władze marokańskie wykazywały się dużą otwartością także na inne państwa, jak na przykład Malta czy Stolica Apostolska. Stosunki Maroka z Francją i Hiszpanią miały charakter asymetryczny - stronę silniejszą stanowiły w nich państwa europejskie - były jednak obustronnie korzystne. Chroniąc własne interesy w Afryce Północnej, potęgi kolonialne wspierały rozwój królestwa, przede wszystkim gospodarczy. Relacje ze Wspólnotą Europejską można odbierać jako swoiste ,przedłużenie” stosunków z Francją oraz, w mniejszym stopniu, z Hiszpanią, ujęte w ramy polityki europejskiej. Warto również podkreślić, że Maroko dobrze odnalazło się w rzeczywistości zimnowojennej, pozostając na uboczu zmagań pomiędzy państwami bloku wschodniego oraz zachodniego i jednocześnie realizując własne interesy, w dużej mierze wymagających dobrych relacji z państwami Zachodu.

Tytułem zakończenia warto podkreślić, że relacje z państwami europejskimi były postrzegane jako perspektywiczne oraz dostrzegano konieczność ich rozwoju w przyszłości. W tym świetle warto wspomnieć o zainteresowaniu ówczesnego następcy tronu, a obecnego król Maroka, Muhammad VI polityką europejską. Na przełomie 1988 i 1989 roku odbył on sześciomiesięczny staż w gabinecie Przewodniczącego Komisji Europejskiej, Jacquesa Delorsa. Kilka lat później, w 1993 roku, obronił z wyróżnieniem rozprawę doktorską z zakresu nauk prawnych na Université de Nice Sophia-Antipolis. Rozprawa doktorska następcy tronu dotyczyła współpracy Europejskiej Wspólnoty Gospodarczej i Unii Maghrebu Arabskiego [Biographie de Sa Majesté...]. Polityka zagraniczna Muhammada VI wobec państw europejskich stanowi kontynuację polityki Hasana II. 
Title: Relations of the Kingdom of Morocco with European states during the reign of Hasan II (1961-1999): selected aspects

\begin{abstract}
The paper elaborates on key aspects of international relations of the Kingdom of Morocco with selected European states - France, Spain, Malta and the Holy See - during the reign of king Hasan II (1961-1999). The work makes reference also to relations of the Kingdom with the European Community. In order to reconstruct the relations of Morocco with the European countries the author analysed primary sources and internet resources and conducted critical analysis of the literature of the subject.
\end{abstract}

Key words: Morocco, Hasan II, Europe, foreign policy, international relations

\title{
BIBLIOGRAFIA
}

Źródła pierwotne

1. Agreement between the Government of the Republic of Malta and the Government of the Kingdom of Morocco concerning the Abolition of Visas, 22 January 1976. Treaty Series no. 157, Department of Information, Malta.

2. Charte de Casablanca (7 janvier 1961). Annuaire de l'Afrique du Nord, Documents Maroc, 1964.

3. Cooperation Agreement between the European Economic Community and the Kingdom of Morocco, 27/09/1978. Official Journal L 264/2.

4. Cultural and Scientific Cooperation Agreement between the Government of the Republic of Malta and the Government of the Kingdom of Morocco, 22 January 1976. Treaty Series no. 152, Department of Information, Malta.

5. Economic and Technical Cooperation Agreement between the Government of the Republic of Malta and the Government of the Kingdom of Morocco, 22 January 1976. Treaty Series no. 153, Department of Information, Malta.

6. Euro-Mediterranean Agreement establishing an association between the European Communities and their Member States, of the one part, and the Kingdom of Morocco, of the other part, 18/03/2000. Official Journal L 070/2.

7. Stqarrija mill-Prim Ministru fil-Kamra tad-Deputati, Żjara ta'delegazzjoni maltija fil-Marokk, Parigi u Londra bejn is-27 u t-30 ta'Novembru, 2 ta' Dicembru 1974, P.M. 28/74.

8. Stqarrija mill-Prim Ministru fil-Kamra tad-Deputati, Żjara tal-Prim Ministru tal-Marokk, 26 ta' Jannar 1976, P.M. 1/76.

9. Trade Agreement between the Government of the Republic of Malta and the Government of the Kingdom of Morocco, 22 January 1976. Treaty Series no. 156, Department of Information, Malta.

\section{Literatura przedmiotu}

1. Benoist-Méchin J., 2010. Histoire des Alaouites. Editions Perrin Mesnil-sur-l'Estrée.

2. Chodubski A.J., 2008. Wstęp do badań politologicznych. Wydawnictwo Uniwersytety Gdańskiego Gdańsk.

3. Dziubiński A., 1983. Historia Maroka. Zakład Narodowy im. Ossolińskich Wrocław. 
4. Holgado Molina M., Ostos Rey M., 2002: Los acuerdos de pesca maritima entre España y Marruecos: evolución histórica y perspectivas. Estudios Agrosociales y Pesqueros, nr 194, 189-216.

5. Jarecka-Stępień K., 2018: Polityka zagraniczna Maroka. W: Wprowadzenie do polityka zagranicznej muzulmańskich państw Bliskiego Wchodu i Afryki Pótnocnej, Woźniak-Bobińska M., Solarz A.M. (red.), Scholar Warszawa, 418-443.

6. Madeyska D., 2008. Historia wspótczesna świata arabskiego, Wydawnictwa Uniwersytetu Warszawskiego Warszawa.

7. Malinowski M., 2004. Sahara Zachodnia. Konflikt terytorialny między Marokiem a Hiszpania w latach 1956-1976, Wydawnictwo Adam Marszałek Toruń.

8. Morales Lezcano V., 2006. Historia de Marruecos. De los orígenes tribales y las poblaciónes nómadas a la independencia y la monarquía actual. La Esfera de los Libros Madrid.

9. Pennell C.R., 2009. Breve historia de Marruecos, Alianza Editorial Madrid.

10. Pérez García G., 2003: La falacia histórica sobre la colonia de Ifni. Historia y Comunicación Social, vol. 8, 207-222.

11. Ryszka F., 1984. Nauka o polityce. Rozważania metodologiczne, Państwowe Wydawnictwo Naukowe Warszawa.

12. Stachurska K., 2004: Polityka Francji wobec Maroka w latach dziewięćdziesiatych XX wieku. Annales Universitatis Mariae Curie-Skłodowska Lublin - Polonia. Sectio K, vol. XI, 39-58.

13. Tsoukalis L., 1977: The EEC and the Mediterranean: Is 'Global' Policy a Misnomer? International Affairs, vol. 53, no. 3, 422-438.

14. Willis M., Messari N., 2003: Analyzing Moroccan Foreign Policy and Relations with Europe. The Review of International Affairs, vol. 3, no. 2, Winter, 152-172.

15. Żebrowski J., 2001. Maroko. Wspótczesność a historia, Wydawnictwo Akademickie Dialog Warszawa.

\section{Strony internetowe}

1. Permanent Observer Mission of the Holy See to the United Nations, Diplomatic Relations Of The Holy See, https://holyseemission.org/contents/mission/diplomatic-relations-of-the-holy-see. php [dostęp: 03.04.2021].

2. Royaume du Maroc, Biographie de Sa Majesté Mohammed VI, https://www.maroc.ma/fr/content/biographie-de-sa-majest\%C3\%A9-mohammed-vi [dostęp: 05.05.2021].

3. The Holy See, Apostolic journey of His Holiness Pope Francis to Morocco, 30-31 March 2019, https://www.vatican.va/content/francesco/en/travels/2019/outside/documents/papa-francesco -marocco-2019.html [dostęp: 05.05.2021] 